
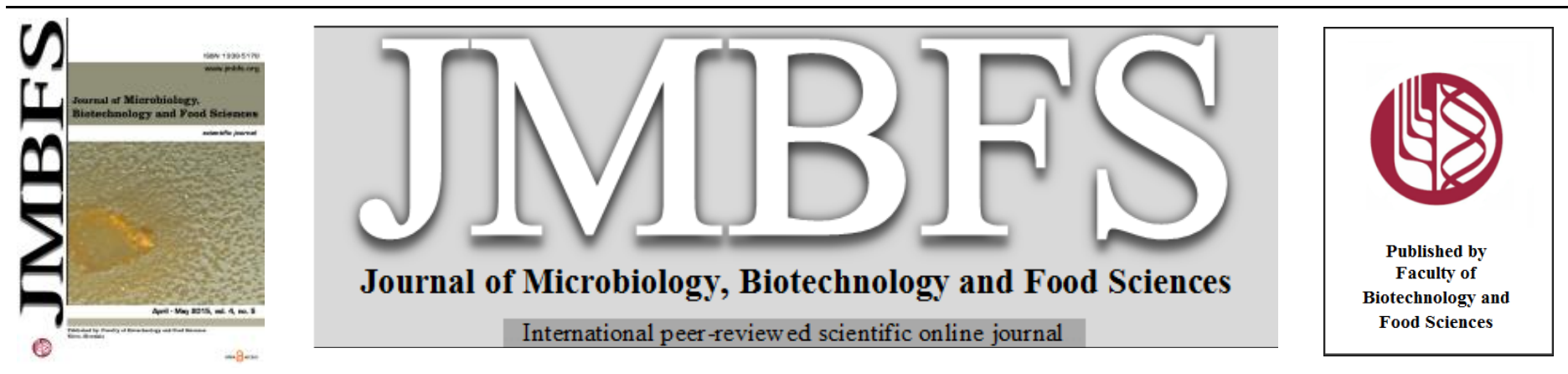

\title{
LIKE IT ACID AND POOR: A STUDY OF ABIOTIC FACTORS INFLUENCING Streptococcus bovis HC5 GROWTH AND BACTERIOCIN PRODUCTION
}

\author{
Ana Andréa Teixeira Barbosa ${ }^{1,2}$, Hilário Cuquetto Mantovani ${ }^{1 *}$, Déborah Romaskevis Gomes Lopes ${ }^{l}$, Henrique Freitas Santana ${ }^{l}$ \\ Address(es): Hilário C. Mantovani, $\mathrm{PhD}$ \\ ${ }^{1}$ Departamento de Microbiologia, Universidade Federal de Viçosa, Viçosa, Minas Gerais, Brazil CEP: 36570-000, Phone: + 55 (31) $3899-1946$ Fax: + 55 (31) 3899 - \\ 2573. \\ ${ }^{2}$ Departamento de Morfologia, Universidade Federal de Sergipe, São Cristóvão, Sergipe, Brasil.
}

*Corresponding author: hcm6@ufv.br

doi: 10.15414/jmbfs.2015.4.5.421-426

\section{ARTICLE INFO}

Received 26. 8. 2014

Revised 28. 11. 2014

Accepted 30.1.2015

Published 1. 4. 2015

Regular article

OPEN ${ }_{\text {ACCESS }}$

\begin{abstract}
This study aimed to investigate the effect of $\mathrm{pH}$, temperature, growth atmosphere and nutrient availability on bovicin HC5 production by Streptococcus bovis HC5. S. bovis HC5 grew well in complex and basal media under aerobic and anaerobic conditions, but greater bacteriocin yields were recovered from anaerobic cultures. Lactate production and glucose consumption increased if S. bovis HC5 cells were cultivated at $\mathrm{pH} 7.0$ and at $45^{\circ} \mathrm{C}$, but higher bovicin $\mathrm{HC} 5$ activity was recovered from cells grown in acidic conditions and at lower temperatures $\left(39^{\circ} \mathrm{C}\right)$. Cultures maintained under continuous $\mathrm{CO}_{2}$ flow showed faster growth rates in basal media, but bacteriocin production was always higher if $S$. bovis was cultivated in anaerobic sealed tubes. These results suggest that acidic $\mathrm{pH}$ and anoxic conditions favor bovicin HC5 production by S. bovis HC5. S. bovis HC5 is a unique lactic acid bacterium in its ability to grow and produce high amounts of a potentially useful bacteriocin in simple media. Considering the constrains for bacteriocin production at commercial scale, it appears that bovicin HC5 production could be achieved at lower costs compared to other bacteriocins from lactic acid bacteria.
\end{abstract}

Keywords: Bovicin HC5, pH, environmental conditions, lactic acid bacteria

\section{INTRODUCTION}

Bacteriocins produced by lactic acid bacteria compose a large and diverse group of ribossomally synthesized, extracellularly released peptides with antibacterial activity against closely related strains (Cleveland $\boldsymbol{e t}$ al., 2001). Some of these antimicrobial peptides are effective in controlling spoilage microorganisms in foods or inhibiting human and animal pathogens (Bowe et al. 2006; Coelho et al. 2007; Carvalho et al. 2008; Hartmann et al. 2011; Crowley et al., 2013; Sharma et al., 2013; Barbosa et al., 2013). Since these characteristics are useful for the pharmaceutical and food industries, there is a great interest in expanding the characterization and production of antimicrobial peptides with potential for commercial applications.

The increase in antibiotic-resistant pathogens has also stimulated the study of bacteriocins as an alternative to classical antibiotic to treat infectious diseases and reduce the risk of selecting antibiotic-resistant strains (Brumfitt et al., 2002; Rea et al., 2007; Piper et al., 2009). Bovicin HC5, a lantibiotic produced by Streptococcus bovis HC5 has wide spectrum of activity, stability to heat and acidic $\mathrm{pH}$ and uses lipid II as its target in the cell membrane (Mantovani et al., 2002; Houlihan et al., 2004; Paiva et al., 2011). Previous studies indicated that bovicin-resistance is not a phenotype easily selected among sensitive bacteria (Mantovani et al., 2001; Mantovani and Russell, 2003a; Carvalho et al., 2007ab). Because of its characteristics, bovicin HC5 has been suggested as a promising peptide to be used for commercial applications (Carvalho et al., 2009; Lima et al., 2010).

In order to be considered for practical applications, large scale production of relatively pure bacteriocins must be obtained and the factors influencing bacteriocin production must be determined. In a previous work, $S$. bovis HC5 was able to produce bovicin HC5 under a wide range of culture conditions (Mantovani and Russell 2003b), and more recent results indicated that carbon and nitrogen sources affect the amount of cell-free and cell-associated bovicin HC5 (Carvalho et al., 2009).

Considering that $S$. bovis HC5 is a facultative anaerobic ruminal bacteria (Mantovani et al., 2001), and the fact that environmental factors and media composition affect bacteriocin production by lactic acid bacteria (Van Den Berghe et al., 2006; Carvalho et al., 2009; Aguilar-Uscanga et al., 2013), this work aimed to investigate the effect of $\mathrm{pH}$, temperature, aeration and different media on bovicin $\mathrm{HC} 5$ production by $S$. bovis $\mathrm{HC} 5$.

\section{MATERIAL AND METHODS}

Microorganisms and culture media

The bacteriocin producer strain Streptococcus bovis HC5 was isolated from the rumen of cattle (Mantovani et al. 2001) and cultivated as previously described (Mantovani and Russell, 2003b) in basal media containing (per litre): $292 \mathrm{mg}$ $\mathrm{K}_{2} \mathrm{HPO}_{4}, 292 \mathrm{mg} \mathrm{KH} \mathrm{KH}_{2} \mathrm{PO}, 480 \mathrm{mg}(\mathrm{NH} 4)_{2} \mathrm{SO}_{4}, 480 \mathrm{mg} \mathrm{NaCl}, 100 \mathrm{mg}$, $\mathrm{MgSO}_{4} .7 \mathrm{H}_{2} \mathrm{O}, 64 \mathrm{mg} \mathrm{CaCl} 2.2 \mathrm{H}_{2} \mathrm{O}, 500 \mathrm{mg}$ cysteine hydrochloride, $1.0 \mathrm{~g}$ Trypticase, $0.5 \mathrm{~g}$ yeast extract, $16 \mathrm{~g}$ glucose and $4.0 \mathrm{~g} \mathrm{Na}_{2} \mathrm{CO}_{3}$. The medium was prepared anaerobically under an $\mathrm{O}_{2}$ free carbon dioxide flux and the final $\mathrm{pH}$ was adjusted to 6.5 with $\mathrm{NaOH}\left(1 \mathrm{~mol} \mathrm{~L}^{-1}\right)$.

The indicator organism, Alicyclobacillus acidoterrestris DSMZ 2498, was grown at $40{ }^{\circ} \mathrm{C}$ in Alicyclobacillus acidoterrestris medium (AAM), described by Yamazaki et al. (2000). AAM was composed of (per liter): yeast extract, $1.0 \mathrm{~g}$, $\left(\mathrm{NH}_{4}\right)_{2} \mathrm{SO}_{4}, 0.2 \mathrm{~g}, \mathrm{MgSO}_{4} \cdot 7 \mathrm{H}_{2} \mathrm{O}, 0.5 \mathrm{~g}, \mathrm{CaCl}_{2} \cdot 2 \mathrm{H}_{2} \mathrm{O}, 0.25 \mathrm{~g}, \mathrm{KH}_{2} \mathrm{PO}_{4}, 1.0 \mathrm{~g}$, glucose, $1.0 \mathrm{~g}$, and distilled water (1000 mL, pH 4.0). Solid medium (AAM agar) was prepared mixing 2-fold concentrated AAM broth $(500 \mathrm{~mL})$ with a $4 \%(\mathrm{w} / \mathrm{v})$ agar stock solution $(500 \mathrm{~mL})$ prepared with distilled water. Each solution was heat-sterilized separately $\left(121^{\circ} \mathrm{C} / 15 \mathrm{~min}\right)$ and mixed while the medium was still hot.

\section{Bovicin HC5 bioassay}

Free bovicin HC5 and the cell-associated bacteriocin were determined in cell-free supernatants and in acidic extracts obtained from $S$. bovis HC5 cells, respectively. The cell-associated bovicin $\mathrm{HC} 5$ was extracted with acidic $\mathrm{NaCl}$, as described by Carvalho et al. (2007a). Free bovicin HC5 in the culture supernatant was determined by harvesting the cell-free supernatant from stationary-phase $S$. bovis HC5 cells. Preparations containing bovicin HC5 were serially diluted (2-fold increments) into $\mathrm{NaCl}$ solution $\left(100 \mathrm{mmol} \mathrm{L}^{-1}, \mathrm{pH} 2.0\right)$ and tested for antimicrobial activity against $A$. acidoterrestris DSMZ 2498 by agar well 
diffusion (Hoover and Harlander, 1993). Bovicin HC5 activity was estimated from zones of clearing around each well and represented as the reciprocal of the highest dilution that still produced a zone of inhibition with at least $10 \mathrm{~mm}$ in diameter. The yield of bovicin HC5 production was calculated by the relation between bacteriocin activity ( $\mathrm{AU} \mathrm{mL} \mathrm{m}^{-1}$ ) and biomass produced (mg cell dry mass). Cell dry mass (biomass) from cultures was determined as described by Carvalho et al. (2009), where the relationship between optical density (600 nm) and cell dry mass for $S$. bovis HC5 was 360 mg cell dry mass liter $^{-1}$ turbidity unit $^{-}$ 1 . To calculate the biomass from cultures, the OD values were multiplied by 0.360 to obtain results per $\mathrm{mL}$. The specific activity of bovicin HC5 was determined by dividing the activity $\left(\mathrm{AU} \mathrm{mL}^{-1}\right)$ by biomass. The activity of bovicin HC5 was expressed as arbitrary units (AU) per mg of cell dry mass (AU $\mathrm{mL}^{-1} \mathrm{mg}^{-1}$ of cell dry mass).

\section{Effect of aeration and media composition on bovicin HC5 production}

S. bovis HC5 was grown in BHI (Becton, Sparks, MD, USA), MRS (Himedia, Mumbai, India), M17 (Sigma, Buchs, Switzerland) or basal media (Mantovani and Russell , 2003b). Media $\mathrm{pH}$ was always adjusted to $\mathrm{pH} 6.5$ with $\mathrm{NaOH}$ (1 $\mathrm{mol}^{-1}$ ) and incubations were carried out under aerobic and anaerobic conditions. The cultures were maintained at $39{ }^{\circ} \mathrm{C}$ and the growth was monitored spectrophotometrically (OD600nm - Spectronic 20D+, Thermo Electron, Madison, WI) at time intervals for $24 \mathrm{~h}$. The cell-free supernatants and the acidic bacteriocin extracts obtained after $16 \mathrm{~h}$ of growth in each medium were tested for bovicin HC5 activity by well diffusion assay. The specific growth rate $(\mu)$ was calculated from the rate of increase in cell biomass $(\mathrm{X})$ based on the equation $\mathrm{dX} / \mathrm{dt}=\mu \mathrm{X}$, where $\mu$ is an absolute rate constant with the units of $\mathrm{h}^{-1}$ and $\mathrm{t}$ is the growth time of in exponential phase. The specific growth rate $\left(\mathrm{h}^{-1}\right)$ was estimated from the differences between the natural logarithm of optical density and time. The final $\mathrm{pH}$ of the cultures were also determined.

$S$. bovis HC5 was also grown in basal media under three different conditions: 1) continuous $\mathrm{CO}_{2}$ flux (CCF), 2) sealed anaerobic tubes (SAT) and 3) aerobic conditions. The changes in optical density and bacteriocin production were monitored during $S$. bovis HC5 growth as described above.

\section{Production of bovicin HC5 at different $\mathrm{pH}$ values and incubation} temperatures

To assess the effect of initial $\mathrm{pH}$ on bovicin HC5 production, S. bovis HC5 was cultivated anaerobically in basal media lacking $\mathrm{Na}_{2} \mathrm{CO}_{3}$. The media $\mathrm{pH}$ was adjusted to values ranging from 4.5 to 7.0 , using $\mathrm{HCl}$ or $\mathrm{NaOH}$ at $1 \mathrm{~mol} \mathrm{~L}^{-1}$. Each tube was inoculated with $3 \%$ (v/v) of an $18 \mathrm{~h}$-old culture of $S$. bovis HC5 and incubated at $39^{\circ} \mathrm{C}$ for $16 \mathrm{~h}$. Growth was monitored at time intervals by determining the changes in OD600nm in a Spectronic 20D+. In another experiment, the culture $\mathrm{pH}$ was maintained at constant values using a $\mathrm{pH}$ controller (Model 5656-00, Cole Parmer, Illinois, USA) to maintain the hydrogen ion concentration in a range that $S$. bovis $\mathrm{HC} 5$ was able to grow (pH 5.5 to 7.0).

$S$. bovis HC5 was grown in $500 \mathrm{~mL}$ fleaker beaker flasks (Corning) that were continuously purged with $\mathrm{O}_{2}$ free carbon dioxide and after incubation for 16 and 24 hours, samples of $50 \mathrm{~mL}$ were withdrawn and OD and bovicin HC5 activity were determined in acidic $\mathrm{NaCl}$ extracts and in cell-free supernatants, as described above. Glucose and fermentation acids in cell-free supernatants were analyzed by high performance liquid chromatography (HPLC, Aminex Bio-Rad HPX-87H organic acid column, $300 \times 7.8 \mathrm{~mm}$ I.D., $9 \mu \mathrm{m}$ particle size). The sample size was $20 \mu \mathrm{l}$, the eluant was $0.005 \mathrm{~mol} \mathrm{~L}^{-1} \mathrm{H}_{2} \mathrm{SO}_{4}$, the flow rate was 0.7 $\mathrm{mL} \mathrm{min}-{ }^{1}$ and the column temperature was $60^{\circ} \mathrm{C}$. Control treatments without $\mathrm{pH}$ control were also performed.

The effect of temperature on $S$. bovis HC5 growth and bovicin production was determined by incubating cultures of $S$. bovis HC5 anaerobically on basal media for $16 \mathrm{~h}$ at temperatures of $25,30,36,39$ and $45^{\circ} \mathrm{C}$. After the incubation time, final $\mathrm{pH}$ and bovicin $\mathrm{HC} 5$ specific activity, expressed as AU per mg of dry cell mass, were determined for all $\mathrm{pH}$ and temperature conditions described above.

\section{Statistics}

All experiments were carried out at least in duplicate and repeated twice. The results obtained were subjected to analysis of variance (ANOVA), and the means were compared by the Tukey test, at $5 \%$ of probability, using the SAS statistical software (Statistical Analysis Systems, 2004). When error bars are given in the figures, they refer to the standard deviation of the mean.

\section{RESULTS}

Effect of growth media on S. bovis HC5 growth and bacteriocin production

When $S$. bovis HC5 was grown in different media, bovicin HC5 was detected in the cell-free supernatant and in the acidic $\mathrm{NaCl}$ extracts obtained from al conditions tested (Tab 1). The specific growth rate and biomass production were always greater if growth conditions were anaerobic. Except for basal media faster growth and greater biomass were associated with decreased bovicin HC5 production (Tab 1).

Table 1 Effect of media composition on growth parameters of Streptococcus bovis HC5 and specific activity of cell-free (supernantant) and cell associated (extract) bovicin HC5.

\begin{tabular}{|c|c|c|c|c|c|}
\hline \multirow[b]{2}{*}{ Parameter } & \multirow[b]{2}{*}{$\begin{array}{l}\text { Growth } \\
\text { condition }\end{array}$} & \multicolumn{4}{|c|}{ Media* } \\
\hline & & MRS & M17 & BHI & $\begin{array}{c}\text { Basal } \\
\text { Media }\end{array}$ \\
\hline \multirow{2}{*}{ Final $\mathrm{pH}^{* *}$} & Aerobiosis & $4.53 \mathrm{ab}$ & $4.33 \mathrm{bA}$ & $4.53 \mathrm{ab}$ & $4.60 \mathrm{aA}$ \\
\hline & Anaerobiosis & $4.19 \mathrm{aB}$ & $4.45 \mathrm{bA}$ & $5.26 \mathrm{cB}$ & $4.20 \mathrm{aB}$ \\
\hline \multirow{2}{*}{$\mu\left(\mathrm{h}^{-1}\right)$} & Aerobiosis & $0.55 \mathrm{aA}$ & $0.41 \mathrm{bA}$ & $0.59 \mathrm{aA}$ & $0.74 \mathrm{cA}$ \\
\hline & Anaerobiosis & $0.73 \mathrm{aB}$ & $0.75 \mathrm{aB}$ & $0.99 \mathrm{bB}$ & $1.15 \mathrm{cB}$ \\
\hline \multirow{2}{*}{$\begin{array}{l}\text { Cell dry } \\
\text { mass } \\
\left(\mathrm{mg} \mathrm{mL}^{-1}\right)\end{array}$} & Aerobiosis & $0.72 \mathrm{aA}$ & $0.73 \mathrm{aA}$ & $0.50 \mathrm{bA}$ & $0.74 \mathrm{aA}$ \\
\hline & Anaerobiosis & $1.44 \mathrm{aB}$ & $1.35 \mathrm{aB}$ & $1.20 \mathrm{bB}$ & $1.15 \mathrm{bB}$ \\
\hline \multirow[b]{2}{*}{$\begin{array}{l}\text { Cell-free } \\
\text { Bovicin HC5 } \\
\text { specific } \\
\text { activity } \\
\left(\text { AU mL } L^{-1}\right. \\
\mathrm{mg}^{-1} \text { dry cell } \\
\text { mass) }\end{array}$} & Aerobiosis & $888 \mathrm{aA}$ & $888 \mathrm{aA}$ & $160 \mathrm{bA}$ & $432 \mathrm{cA}$ \\
\hline & Anaerobiosis & $83 \mathrm{aB}$ & $178 \mathrm{bB}$ & $133 \mathrm{cB}$ & $914 \mathrm{~dB}$ \\
\hline \multirow{2}{*}{$\begin{array}{l}\text { Cell- } \\
\text { associated } \\
\text { Bovicin HC5 } \\
\text { specific } \\
\text { activity } \\
\text { (AU mL }{ }^{-1} \\
\text { mg }^{-1} \text { dry cell } \\
\text { mass) }\end{array}$} & Aerobiosis & $444 \mathrm{aA}$ & $333 \mathrm{bA}$ & $80 \mathrm{cA}$ & $1,730 \mathrm{dA}$ \\
\hline & Anaerobiosis & $28 \mathrm{aB}$ & $80 \mathrm{bB}$ & $67 \mathrm{cB}$ & $5,485 \mathrm{~dB}$ \\
\hline
\end{tabular}

Legend: * Means for the same parameter followed by at least one same letter uppercase in column and lowercase in line, did not differ significantly by Tukey test at $5 \%$ probability, $* *$ Initial $\mathrm{pH}$ was 6.5

When MRS, M17 or BHI broth were used, the lower specific growth rates attained at aerobic conditions was related to a greater bovicin HC5 activity, particularly in the cell-free supernatant (Tab 1). However, the reverse was observed for the basal media. In this latter treatment, higher cell densities and specific growth rates were related with greater bovicin HC5 production in the cell extract (Tab 1). Because complex media seemed to reduce bacteriocin yield, basal media was chosen to be used in subsequent experiments.

\section{Effect of pH and temperature on bovicin HC5 production}

Batch culture experiments indicated that S. bovis HC5 could grow anaerobically in basal medium even if the initial $\mathrm{pH}$ was as low as 5.5 , but the growth rate and final optical density increased at higher $\mathrm{pH}$ values (Tab 2). Cell-associated bovicin HC5 specific activity was highest (4923 AU mL $\mathrm{mg}^{-1}$ dry cell mass) in basal media at $\mathrm{pH} 6.5$, but it reduced approximately $67 \%, 70 \%$ and $90 \%$ if the initial $\mathrm{pH}$ was 5.5, 6.0 and 7.0, respectively (Tab 2). 
Table 2 Effect of medium $\mathrm{pH}$ on growth parameters and bovicin HC5 production by Streptococcus bovis HC5

\begin{tabular}{|c|c|c|c|c|c|}
\hline \multirow{2}{*}{ Initial pH } & \multirow{2}{*}{ Final pH* } & \multirow{2}{*}{ Final OD* } & \multirow{2}{*}{$\begin{array}{l}\mu^{*} \\
\left(\mathbf{h}^{-1}\right)\end{array}$} & \multicolumn{2}{|c|}{$\begin{array}{l}\text { Bovicin HC5 specific activity } \\
\left(\text { AU } \mathbf{m L}^{-1} \mathrm{mg}^{-1} \text { dry cell mass)* }\right.\end{array}$} \\
\hline & & & & Supernatant & Extract \\
\hline 4.50 & $4.50 \mathrm{ab}$ & $0.136 \mathrm{e}$ & $\overline{\mathrm{NG}}$ & $0 \mathrm{e}$ & $0 \mathrm{e}$ \\
\hline 5.00 & $5.00 \mathrm{a}$ & $0.13 \mathrm{e}$ & $\mathrm{NG}$ & $0 \mathrm{e}$ & $0 \mathrm{e}$ \\
\hline 5.50 & $4.00 \mathrm{bc}$ & $0.54 d$ & $0.45 d$ & $400.00 \mathrm{a}$ & $1,600.00 \mathrm{~b}$ \\
\hline 6.00 & $3.80 \mathrm{c}$ & $1.25 \mathrm{c}$ & $0.82 \mathrm{c}$ & $355.00 \mathrm{~b}$ & $1,422.00 \mathrm{c}$ \\
\hline 6.50 & $4.18 b c$ & $2.90 \mathrm{~b}$ & $0.95 b$ & $307.00 \mathrm{c}$ & $4,923.00 \mathrm{a}$ \\
\hline 7.00 & $3.00 \mathrm{~d}$ & $3.79 a$ & $1.15 \mathrm{a}$ & $235.00 d$ & $470.00 d$ \\
\hline
\end{tabular}

Legend: $\mathrm{NG}=\mathrm{No}$ growth, $*$ Means with the same letter in the column are not significantly different by Tukey test at $5 \%$ probability.

When $S$. bovis HC5 was grown in basal medium with pH control, bovicin HC5 specific activity increased with the reduction in the media $\mathrm{pH}$ (Tab 3). Higher bacteriocin activity was observed if the $\mathrm{pH}$ was maintained at 5.5, independently of the incubation time (Tab 3). The bovicin HC5 activity in the cell extract at this
$\mathrm{pH}$ value was approximately 100 times higher than control treatments after $24 \mathrm{~h}$ of incubation (Tab 3). At pH 6.0 and 6.5, bovicin HC5 specific activity was lower than at $\mathrm{pH} 5.5$, but approximately $70 \%$ higher than control (Tab 3). Bovicin HC5 activity was not detected in the culture supernatant when the $\mathrm{pH}$ was maintained at 6.5 and 7.0 (Tab 3).

Table 3 Effect of controlled $\mathrm{pH}$ on bovicin HC5 production by Streptococcus bovis HC5. Control treatment without pH control is also shown.

\begin{tabular}{|c|c|c|c|c|c|c|}
\hline \multirow{2}{*}{ Parameter } & \multirow{2}{*}{$\begin{array}{l}\text { Time } \\
\text { (h) }\end{array}$} & \multicolumn{5}{|l|}{ pH* } \\
\hline & & 5.5 & 6.0 & 6.5 & 7.0 & Control \\
\hline \multirow{2}{*}{$\begin{array}{l}\text { Biomass } \\
\left(\mathrm{mg} \mathrm{mL}^{-1}\right)\end{array}$} & 16 & $1.17 \mathrm{abA}$ & $1.20 \mathrm{abA}$ & $1.29 \mathrm{aA}$ & $1.02 \mathrm{bcA}$ & $0.90 \mathrm{cA}$ \\
\hline & 24 & $1.37 \mathrm{aA}$ & $1.37 \mathrm{abA}$ & $1.39 \mathrm{bA}$ & $0.96 \mathrm{acA}$ & $1.03 \mathrm{cA}$ \\
\hline \multirow{2}{*}{$\begin{array}{l}\text { Supernatant Bovicin } \\
\text { HC5 specific activity } \\
\text { (AU mL } \mathrm{mg}^{-1} \text { dry } \\
\text { cell mass) }\end{array}$} & 16 & $3,096.00 \mathrm{aA}$ & $254.00 \mathrm{bA}$ & $0 \mathrm{cA}$ & $0 \mathrm{cA}$ & $1,536.00 \mathrm{dA}$ \\
\hline & 24 & $66,064.00 \mathrm{aB}$ & $3,047.00 \mathrm{bB}$ & $0 \mathrm{cA}$ & $0 \mathrm{cA}$ & $604.00 \mathrm{~dB}$ \\
\hline \multirow{2}{*}{$\begin{array}{l}\text { Cell Extract Bovicin } \\
\text { HC5 specific activity } \\
\text { (AU mL } \mathrm{mg}^{-1} \text { dry } \\
\text { cell mass) }\end{array}$} & 16 & $23,032.00 \mathrm{aA}$ & $14,380.00 \mathrm{aA}$ & $14,576.00 \mathrm{abA}$ & $1,184.00 \mathrm{bcA}$ & $4,960.00 \mathrm{cA}$ \\
\hline & 24 & $518,516.00 \mathrm{aB}$ & $14,380.00 \mathrm{bA}$ & $11,288.00 \mathrm{bA}$ & $0 \mathrm{cA}$ & $4,490.00 \mathrm{bcA}$ \\
\hline
\end{tabular}

Legend: * Means for the same parameter followed by at least one same letter, uppercase in column and lowercase in line, did not differ significantly by Tukey test at $5 \%$ probability.

Control treatment showed similar levels of bovicin HC5 activity in the acidic extract after 16 and 24 hours of incubation, which was also observed for $\mathrm{pH} 6.0$ and 6.5 (Tab 3). However, in pH 5.5 the bacteriocin activity increased more than 20 -fold after 24 hours of incubation. Bovicin HC5 was not detected by S. bovis HC5 cultures maintained for $24 \mathrm{~h}$ at $\mathrm{pH}$ 7.0. Biomass production by $S$. bovis HC5 after $24 \mathrm{~h}$ of incubation at $\mathrm{pH}$ values ranging from 5.5 to 6.5 averaged $1.35 \mathrm{mg}$ $\mathrm{mL}^{-1}$ (Tab 3). At pH 7.0 and in the controls, lower values of microbial biomass were obtained (Tab 3). When the culture supernatant was analyzed by HPLC, lactate was the only metabolic product of glucose fermentation. Lactate concentration and residual glucose increased at higher $\mathrm{pH}$ values (Fig 1).

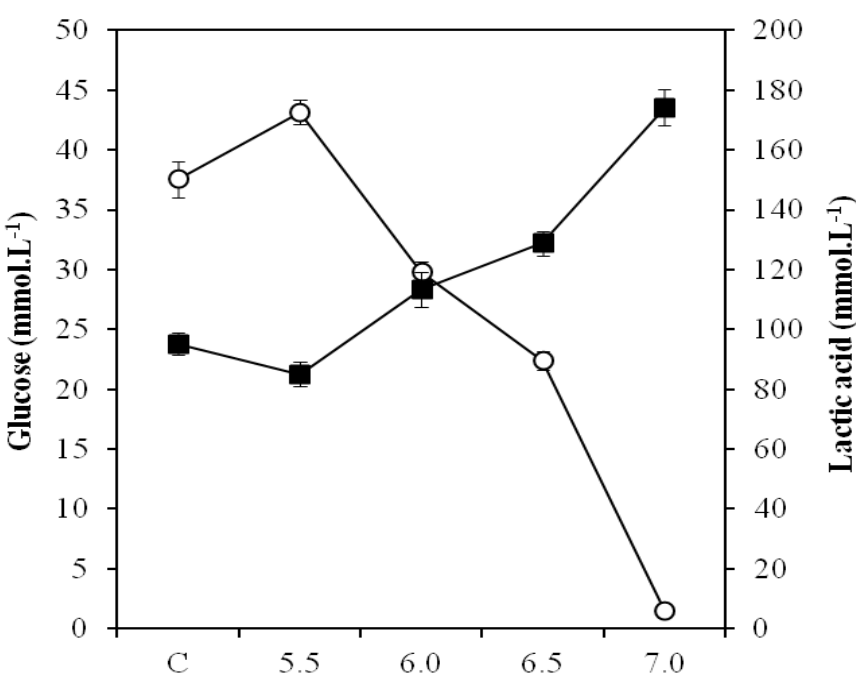

Figure 1 The consumption of glucose (open circles) and production of lactic acid (closed circles) by $S$. bovis HC5 grown at different $\mathrm{pH}$ values. S. bovis was inoculated into basal media added with glucose at $16 \mathrm{~g} \mathrm{~L}^{-1}$ and the media $\mathrm{pH}$ was maintained at 5.5, 6.0, 6.5 and 7.0. After 24 hours of incubation samples were taken and fermentation end-products and residual glucose were analyzed in culture supernatants. The control treatment (C) without $\mathrm{pH}$ control is also shown.

If $S$. bovis $\mathrm{HC} 5$ was cultivated in basal media ( $\mathrm{pH}$ 6.5) at different temperatures, growth occurred at temperatures ranging from $30^{\circ} \mathrm{C}$ to $45^{\circ} \mathrm{C}$ (Fig 2). Culture $\mathrm{pH}$ after $16 \mathrm{~h}$ of incubation was approximately 4.0 and typical optical densities varied from 2.0 at $30^{\circ} \mathrm{C}$ through $39^{\circ} \mathrm{C}$ to 2.6 at $45^{\circ} \mathrm{C}$ (Fig 2a). Approximate levels of $13000 \mathrm{AU} \mathrm{mL} \mathrm{mg}^{-1} \mathrm{mg}$ cell dry mass ${ }^{-1}$ of bovicin $\mathrm{HC} 5$ were obtained when $S$. bovis $\mathrm{HC} 5$ was incubated at $30^{\circ} \mathrm{C}, 36^{\circ} \mathrm{C}$ or $39^{\circ} \mathrm{C}$. However, a decrease in activity of approximately $20 \%$ was observed at $45^{\circ} \mathrm{C}$ (Fig $2 \mathrm{~b}$ ). 

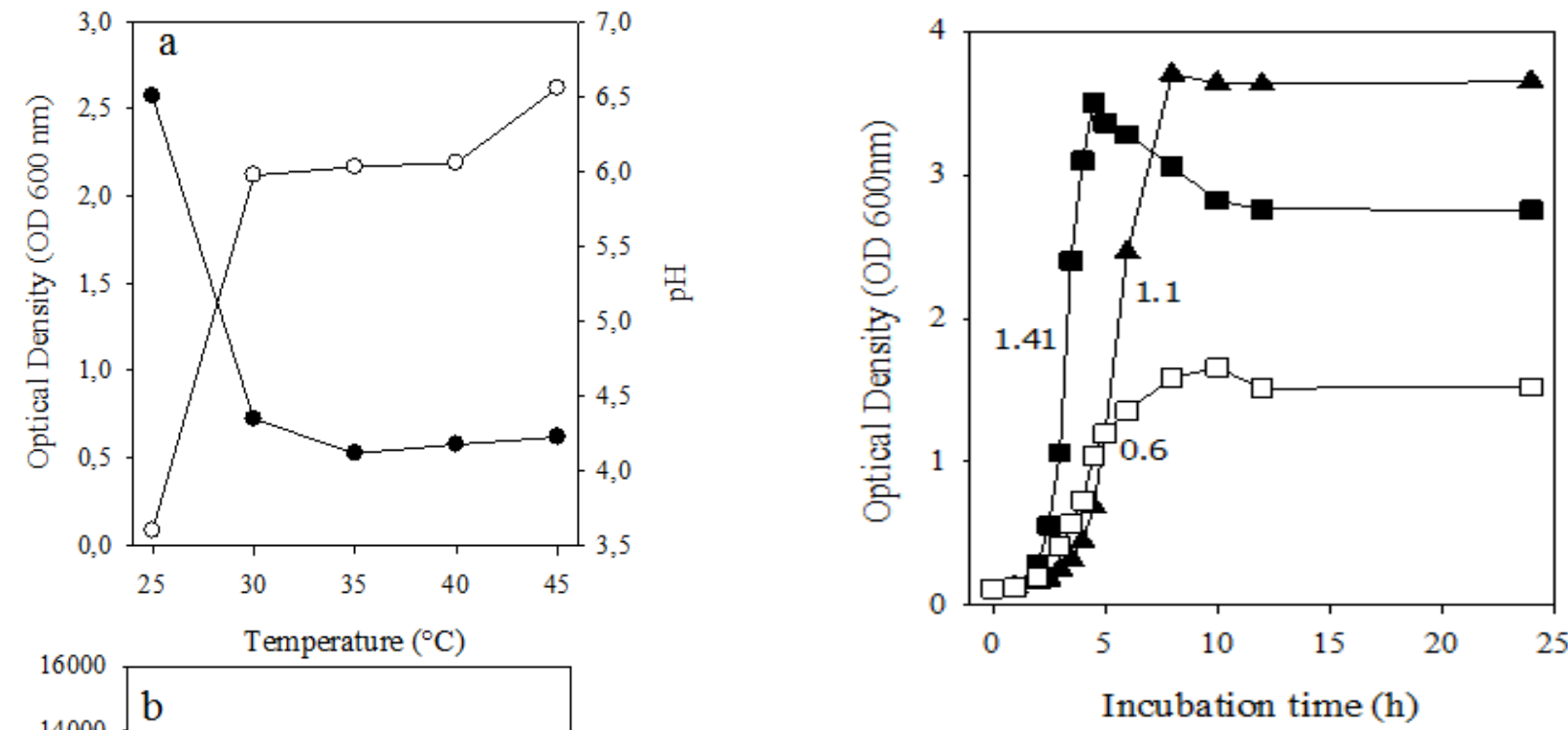

Figure 3 The effect of growth atmosphere on S. bovis HC5 growth. S. bovis HC5 was incubated under aerobic condition (open squares), continuous $\mathrm{CO}_{2}$ flow (closed squares) and in sealed anaerobic tubes (closed triangles). The cultures were maintained at $39^{\circ} \mathrm{C}$ and the growth was monitored by changes in optical density $\left(\mathrm{OD}_{600 \mathrm{~nm}}\right)$. The estimated specific growth rates $\left(\mathrm{h}^{-1}\right)$ for $S$. bovis HC5 are indicated for each growth condition.

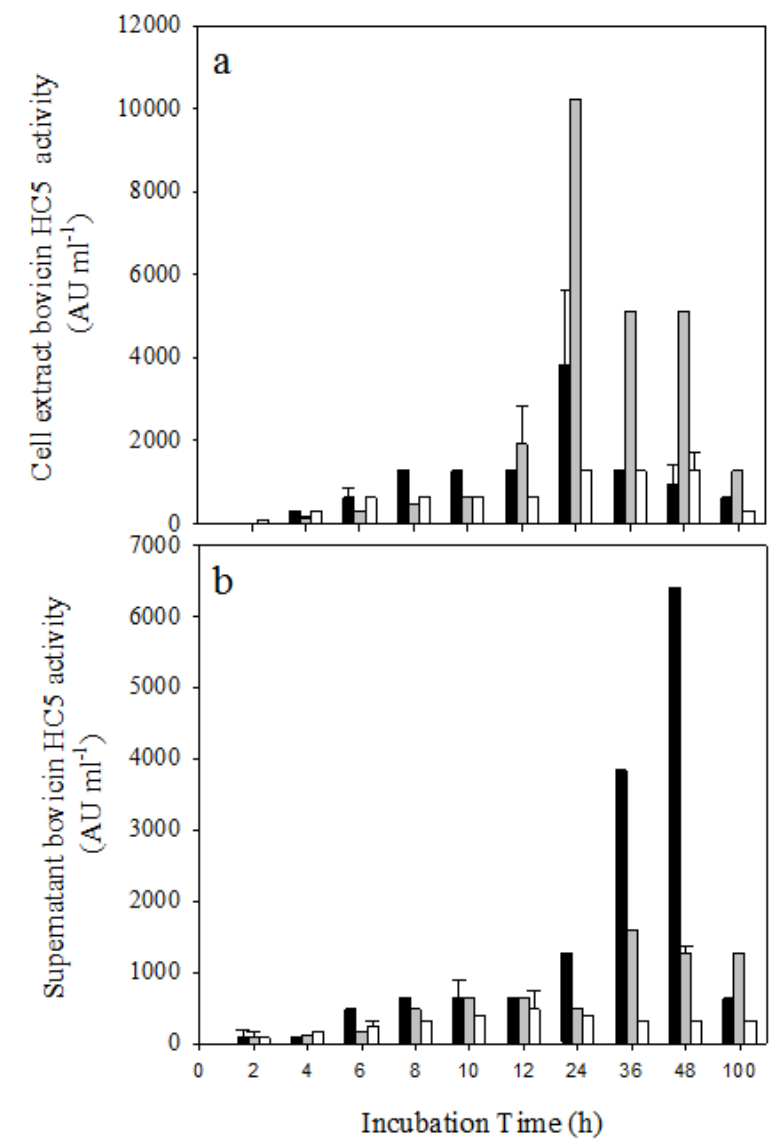

Figure 2 Effect of incubation temperature on $S$. bovis HC5 growth and bovicin HC5 production. $S$. bovis HC5 was cultivated anaerobically in basal media (pH 6.5) incubated for $24 \mathrm{~h}$ at temperatures ranging from $25^{\circ} \mathrm{C}$ to $45^{\circ} \mathrm{C}$. (a) The final $\mathrm{pH}$ (closed circles) and the OD600 nm (open circles) were measured. The specific activity of cell-associated bovicin HC5 against A. acidoterrestris DSMZ 2498 is indicated in (b).

Growth and bacteriocin production by $S$. bovis in basal media at different aeration conditions

When $S$. bovis HC5 was cultivated in basal media ( $\mathrm{pH}$ 6.5) under conditions of continuous $\mathrm{CO}_{2}$ flux (CCF), sealed anaerobic tubes (SAT) and aerobic condition, the lag phase duration of the bacteriocin producer strain was at least 2 hours (Fig 3 ). However, the specific growth rate was greater in CCF and maximal biomass production was observed in SAT (Fig 3).

Bovicin HC5 was monitored during $S$. bovis HC5 growth and inhibitory activity was detected for all conditions tested (Fig 4). Bacteriocin production was observed after 2 hours of aerobic growth $\left(160 \mathrm{AU} \mathrm{mL} \mathrm{m}^{-1}\right)$ or $4 \mathrm{~h}$ of anaerobic growth (320 AU mL $\left.\mathrm{m}^{-1}\right)$. The increase in bovicin HC5 activity was faster under CCF condition (Fig 4). Maximal bacteriocin activity (AU mL ${ }^{-1}$ ) was observed in the acidic cell-extract at $24 \mathrm{~h}$ of growth, and the activity was higher when $S$ bovis was cultivated in sealed tubes (10240 AU mL $\mathrm{mL}^{-1}$, Fig 4).

Bovicin HC5 activity reduced about $33 \%$ and $50 \%$ after 36 hours of incubation in continuous $\mathrm{CO}_{2}$ flux and sealed tubes, respectively. Under aerobic conditions this decrease in bacteriocin activity was not observed at $24 \mathrm{~h}$ of incubation (Fig 4). However, after $48 \mathrm{~h}$, reduction in bovicin HC5 activity was observed for all conditions tested, being more pronounced for cultures growing in SAT (Fig 4).

Figure 4 Production of bovicin HC5 under aerobic conditions (white bars), continuous $\mathrm{CO}_{2}$ flow (black bars) and sealed anaerobic tubes (gray bars). At each time interval, samples were taken and bovicin HC5 activity (AU mL ${ }^{1}$ ) in the cell extract (a) and in the culture supernatant (b) were determined using $A$ acidoterrestris DSMZ 2498 as the indicator organism. 


\section{DISCUSSION}

Lactic acid bacteria are fastidious organisms that often require complex media to sustain the production of biomass and the biosynthesis of metabolites with industrial applications, including antimicrobial peptides (Kim et al., 2006). Previous work demonstrated that strains of Pediococcus acidilactici (Anastasiadou et al. 2008), Lactococcus lactis (De Vuyst et al., 1996), Micrococcus sp. GO5 (Kim et al,. 2006) and Lactobacillus rhamnosus (AguilarUscanga et al., 2013) grow better and produce more bacteriocin in complex media. To be commercially attractive, bacteriocins should be obtained at high yields, preferentially, in inexpensive media (Aguilar-Uscanga et al., 2013).

Several studies have tested alternative or lower cost carbon and nitrogen sources to produce bacteriocins (Todorov et al., 2004; Metsoviti et al., 2011; AguilarUscanga et al., 2013). However, most lactic acid bacteria require complex media to growth and cannot sustain anabolism in the absence of several growth factors, including vitamins and amino acids.

Streptococcus bovis HC5 is an unusual lactic acid bacterium that has only few nutritional requirements, being able to use ammonia as the sole nitrogen source (Wolin et al., 1959). Previous studies also showed that $S$. bovis HC5 can produce high levels of bovicin HC5 using sugar cane juice and cheese whey as the only source of carbon and nitrogen (Carvalho et al., 2009).

In this work, S. bovis HC5 grew better and produced greater levels of bovicin HC5 in basal media than in complex media (MRS, BHI or M17) generally used to grow lactic acid bacteria. Cultivation of $S$. bovis HC5 in rich media not only reduced overall bacteriocin production, but also induced the secretion of the peptide in the supernatant, a characteristic that did not depend on the presence or absence of oxygen for growth. On the other hand, growth of S. bovis HC5 in basal media induced greater bacteriocin production and much more of the peptide remained attached to the cells

This feature appears ecologically sound to a bacterium isolated from the bovine rumen, an ecosystem where the concentration of free sugars and amino acids is often very low and the competition for nutritional resources is usually very high (Eijsink et al,. 2002; Nigutova et al., 2007). In order to outcome its competitors in a highly populated environment, it would be advantageous to regulate bacteriocin production according to the growth condition (Eijsink $\boldsymbol{e t}$ al., 2002) In this way, if resources are readily available, more carbon and energy will be diverted to biomass instead of bacteriocin production.

The fact that more bovicin HC5 remains attached to the producer cells is also advantageous for the purification of the peptide, as it can be easily separated from the components of the growth medium, and one chromatographic step can be used to purify the extracts containing bovicin HC5 (Paiva et al., 2011). Results obtained by Mantovani and Russell (2003b), Houlihan et al., (2004) and Xavier et al. (2006) suggest that cell-associated bovicin HC5 could be more important than cell-free activity, being a critical factor in colonization in the rumen (Russell and Mantovani, 2002).

Besides nutrient availability, other growth conditions such as $\mathrm{pH}$, temperature and incubation atmosphere also have great influence on bacteriocin production by lactic acid bacteria (Leroy and De Vuyst, 1999; Mataragas et al., 2003; ElShouny et al., 2012). Temperature and $\mathrm{pH}$ not only affect the growth of the producer strain but also interferes with the stability of the peptide during posttranslational modification. In addition, temperature and $\mathrm{pH}$ can also modify the aggregation, absorption, proteolysis and the activity of the bacteriocin (Cheigh $\boldsymbol{e}$ al., 2002; Drosinos et al., 2006)

$\mathrm{S}$. bovis HC5 was able to grow and produce bovicin $\mathrm{HC} 5$ in basal media at $\mathrm{pH}$ values ranging from 5.5 to 7.0 and temperatures from $30^{\circ} \mathrm{C}$ to $45^{\circ} \mathrm{C}$. High growth rates and biomass production were obtained when $\mathrm{S}$. bovis $\mathrm{HC} 5$ was cultivated at $\mathrm{pH} 7.0$ and incubated at $45^{\circ} \mathrm{C}$. However, maximal bovicin $\mathrm{HC} 5$ production was detected when the initial $\mathrm{pH}$ was 6.5 and the temperatures varied from $30^{\circ} \mathrm{C}$ to $39^{\circ} \mathrm{C}$. The fact that the conditions for optimal bacteriocin production did not coincide with the optimum growth conditions for $S$. bovis HC5 was also reported for other bacteriocin-producing strains (Aasen et al., 2000; Mataragas et al., 2003; Drosinos et al., 2006)

Our results indicated that initial $\mathrm{pH}$ values below and above 6.5 had a negative impact on bovicin HC5 production. The observation that little bacteriocin activity was detected at lower $\mathrm{pH}$ values could be explained by the fact that at these $\mathrm{pH}$ conditions the growth of $S$. bovis HC5 is impaired, which also limits bacteriocin production (Tab 2). Houlihan et al. (2004) did not study the effect of $\mathrm{pH}$ on bacteriocin production by $\mathrm{S}$. bovis $\mathrm{HC} 5$, but showed that bovicin HC5 activity was highly $\mathrm{pH}$-dependent and enhanced at acidic conditions. Because we always used acidic solution to access bovicin HC5 activity in this study, the difference in bacteriocin activity is attributed to bacteriocin production rather than activity. Based on these results, it appears that $\mathrm{pH}$ could influence bovicin HC5 production.

To confirm the role of medium $\mathrm{pH}$ on bovicin $\mathrm{HC} 5$ production, cultures of $S$ bovis $\mathrm{HC} 5$ were maintained at constantly $\mathrm{pH}$ value during growth in basal media (Tab 3). At this condition, the bovicin HC5 activity at pH 5.5 was at least 100 fold greater than the activity recovered from cultures with only the initial $\mathrm{pH}$ adjusted (Tab 2 and 3). In an earlier work, Mantovani and Russell (2003b) reported a 2-fold increase in the antibacterial activity of $S$. bovis HC5 grown in continuous culture when the $\mathrm{pH}$ was decreased from 6.7 to 5.4. The increase in specific activity of bovicin HC5 cannot be explained by a greater amount of ionized carboxyl groups in the cell envelope, which could modify the net negative charge of the cell and the binding affinity of the peptide to the producer cells. The decrease in $\mathrm{pH}$ increased the activity of bovicin HC5 in the cell-free supernatant, but the cell-attached bacteriocin also showed a dramatic increase in activity, which suggest that the regulation of bacteriocin production was being affected by media $\mathrm{pH}$

Temperature had only a modest effect on synthesis of microbial biomass and bovicin HC5 production in S. bovis $\mathrm{HC5}$. In the range of temperature usually used for growth of $S$. bovis $\mathrm{HC} 5\left(39^{\circ} \mathrm{C}-41^{\circ} \mathrm{C}\right)$, the level of bovicin $\mathrm{HC} 5$ remained high, indicating that $\mathrm{pH}$, rather than temperature, has a much more pronounced effect on bacteriocin production.

Previous work showed that lactic acid bacteria can grow under microaerophilic to strictly anaerobic condition (Klein et al., 1998). Although the production of many lactic acid bacteriocins has been studied under strict anaerobic conditions, at least to some bacteriocins (e.g. nisin), an oxygen-enriched atmosphere can enhance the production of antimicrobial peptides (Cabo et al., 2001). As shown if Fig 2, S. bovis HC5 also have the ability to grow and produce bacteriocin under aerobic conditions. However, in the presence of oxygen, the specific growth rate of $S$. bovis HC5 and the levels of cell-free and cell-associated bovicin HC5 were much lower than the anaerobic cultures.

Neysens and De Vuyst (2005) showed that amylovorin titers were higher when the producer strain was maintained under anaerobic condition, and highest under carbon dioxide flow rates. In the case of $S$. bovis HC5, the effect of a continuous $\mathrm{CO}_{2}$ supply on the growth media reflected in a high specific growth rate and a decreased production of cell-associated bovicin HC5 compared to the cultures maintained in anaerobic sealed tubes.

\section{CONCLUSION}

In conclusion, our results show that culture $\mathrm{pH}$, temperature and incubation atmosphere influence bovicin HC5 production and optimization of the growth conditions is required to improve the activity recovered from $\mathrm{S}$. bovis $\mathrm{HC} 5$ cells Bacteriocin production was favored under conditions of controlled $\mathrm{pH}(5.5)$, anaerobiosis and incubation temperature of $39{ }^{\circ} \mathrm{C}$. Based on the ability of $S$. bovis HC5 to grow in simple media and produce large amounts of bovicin HC5, further work will be needed to obtain bovicin HC5 at high yields and lower costs, compared to other bacteriocins produced by fastidious lactic acid bacteria.

Acknowledgments: The authors thank the Conselho de Desenvolvimento Científico e Tecnológico (CNPq, Brasília, Brazil), The Fundação de Amparo à Pesquisa do Estado de Minas Gerais (FAPEMIG, Belo Horizonte, Brazil) and the Coordenação de Aperfeiçoamento de Pessoal de nível Superior (CAPES, Brasília, Brazil), for providing fellowships and financial support for this research.

\section{REFERENCES}

AASEN, I.M., MORETRO, T., KATLA, T., AXELSSON, L., STORRO, I. 2000 Influence of complex nutrients, temperature and $\mathrm{pH}$ on bacteriocin production by Lactobacillus sakei CCUG 42687. Applied Microbiology and Biotechnology, 53(2), 159-166. http://dx.doi.org/10.1128/AEM.70.9.5081-5088.2004

AGUILAR-USCANGA, B.R., SOLÍS-PACHECO, J. R., PLASCENCIA, L., AGUILAR-USCANGA M.G., GARCÍA, H.S., LACROIX, M. 2013. Effect of culture medium on bacteriocin production by Lactobacillus rhamnosus HN001 and Lactobacillus reuteri ATCC 53608. Journal of Microbiology, Biotechnology and Food Sciences, 2(6), 2462-2468. ANASTASIADOU, S., PAPAGIANNI, M., FILIOUSIS, G., AMBROSIADIS, I., KOIDIS, P. 2008. Pediocin SA-1, an antimicrobial peptide from Pediococcus acidilactici NRRL B5627: Production conditions, purification and characterization. Bioresource Technology, 99(13), 5384-5390. http://dx.doi.org/10.1016/j.biortech.2007.11.015

BARBOSAA, A.A.T., SILVA DE ARAÚJO, H.G., MATOS, P.N., CARNELOSSI, M.A.G., CASTRO, A.A. Effects of nisin-incorporated films on the microbiological and physicochemical quality of minimally processed mangoes. International Journal of Food Microbiology, 164(2), 135-140. http://dx.doi.org/10.1016/j.ijfoodmicro.2013.04.004

BOWE, W.P., FILIP, J.C., DIRIENZO, J.M., VOLGINA, A., MARGOLIS, D.J 2006. Inhibition of Propionibacterium acnes by bacteriocin-like inhibitory substances (BLIS) produced by Streptococcus salivarius. Journal of Drugs in Dermatology, 5(9), 868-870.

BRUMFITT, W., SALTON, M.R., HAMILTON-MILLER, J.M. 2002. Nisin, alone and combined with peptidoglycan-modulating antibiotics: activity against methicillin-resistant Staphylococcus aureus and vancomycin-resistant enterococci. Journal of Antimicrobial Chemotherapy, 50(5), 731-734 http://dx.doi.org/10.1093/jac/dkf190

CABO, M.L., MURADO, M.A., GONZALES, M.P., PASTORIZA, L. 2001 Effects of aeration and $\mathrm{pH}$ gradient on nisin production: A mathematical model. Enzyme and Microbial Technology, 29(5), 64-273. http://dx.doi.org/10.1016/S0141-0229(01)00378-7 
CARVAlHO, A.A.T., COSTA, E.D., MANTOVANI, H.C., VANETTI, M.C.D 2007a. Effect of bovicin HC5 on growth and spore germination of Bacillus cereus and Bacillus thuringiensis isolated from spoiled mango pulp. Journal of Applied Microbiology, 102(4), 1000-1009. http://dx.doi.org/10.1111/j.13652672.2006.03160.x

CARVALHO, A.A.T., MANTOVANI, H.C., VANETTI, M.C.D. 2007b. Bactericidal effect of bovicin HC5 and nisin against Clostridium tyrobutyricum isolated from spoiled mango pulp. Letters in Applied Microbiology, 45(1), 68-74. http://dx.doi.org/10.1111/j.1472-765X.2007.02150.x

CARVALHO, A.A.T., MANTOVANI, H.C., PAIVA, A.D., MELO, M.R. 2009 The effect of carbon and nitrogen sources on bovicin HC5 production by Streptococcus bovis HC5. Journal of Appled Microbiology, 107(1), 339-347. http://dx.doi.org/10.1111/j.1365-2672.2009.04212.x

CARVALHO, A.A.T., VANETTI, M.C., MANTOVANI, H.C. 2008. Bovicin HC5 reduces thermal resistance of Alicyclobacillus acidoterrestris in acidic mango pulp. Journal of Applied Microbiology, 104(6), 1685-1691. http://dx.doi.org/10.1111/j.1365-2672.2007.03710.x

CHEIGH, C.I., CHOI, H.J., PARK, H., KIM, S.B., KOOK, M.C., KIM, T.S. HWANG, J.K., PYUN, Y.R. 2002. Influence of growth conditions on the production of a nisin-like bacteriocin by Lactococcus lactis subsp. lactis A164 isolated from kimchi. Journal of Biotechnology, 95(3), 225-235. http://dx.doi.org/10.1016/S0168-1656(02)00010-X

CLEVELAND, J., MONTVILLE, T.J., NES, I.F., CHIKINDA, M.L. 2001. Bacteriocins: safe, natural antimicrobials for food preservation. International Journal of Food Microbiology, 71(1), 1-20.

COELHO, M.L.V., NASCIMENTO, J.S., FAGUNDES, P.C., MADUREIRA, D.J., OLIVEIRA, S.S., BRITO, M.A.V.P., BASTOS, M.C.F. 2007. Activity of staphylococcal bacteriocins against Staphylococcus aureus and Streptococcus agalactiae involved in bovine mastitis. Research in Microbiology, 158(7), 625630. http://dx.doi.org/10.1016/j.resmic.2007.07.002

CROWLEY, S., MAHONY, J., VAN SINDEREN, D. 2013. Broad-spectrum antifungal-producing lactic acid bacteria and their application in fruit models Folia Microbiologica 58(4), 291-299. http://dx.doi.org/10.1007/s12223-0120209-3

DE VUYST, L., CALLEWAERT, R., CRABBE, K. 1996. Primary metabolite kinetics of bacteriocin biosynthesis by Lactobacillus amylovorus and evidence for stimulation of bacteriocin production under unfavourable growth conditions Microbiology, 142(4), 817-827. http://dx.doi.org/10.1099/00221287-142-4-817 DROSINOS, E.H., MATARAGAS, M., METAXOPOULOS, J. 2006. Modeling of growth and bacteriocin production by Leuconostoc mesenteroides E131. Meat Science, 74(4), 690-696. http://dx.doi.org/10.1016/i.meatsci.2006.05.022 EIJSINK, V.G., AXELSSON, L., DIEP, D.B., HAVARSTEIN, L.S., HOLO, H., NES, I.F. 2002. Production of class II bacteriocins by lactic acid bacteria: an example of biological warfare and communication. Antonie Van Leeuwenhoek 81(4), 639-654

EL-SHOUNY, W., ABO-KAMAR, A. EL-SHANSHOURY, A.E.R., RAGY, S. 2012.Production of plantaricin by lactobacillus plantarum sr18.Journal of Microbiology, Biotechnology and Food Sciences, 1(6), 1488-1504.

HARTMANN, H.A., WILKE, T., ERDMANN, R. 2011.Efficacy of bacteriocincontaining cell-free culture supernatants from lactic acid bacteria to contro Listeria monocytogenes in food.International Journal of Food Microbiology, 146(2), 192-199. http://dx.doi.org/10.1016/j.ijfoodmicro.2011.02.031

HOOVER, D.G., HARLANDER, S.K. 1993. Screening methods for detecting bacteriocin activity. In: Hoover, D.G., Steenson, L.R. Bacteriocins of Lactic Acid Bacteria.Food Science and Technology, 23-39.

HOULIHAN, A.J., MANTOVANI, H.C., RUSSELL, J.B. 2004. Effect of pH on the activity of bovicin HC5, a bacteriocin from Streptococcus bovis HC5. FEMS Microbiol Letters, 231(1), 27-32 http://onlinelibrary.wiley.com/doi/10.1016/S0378-1097\%2803\%2900922-4/pdf KIM, M.H., KOMG, Y.J., BAEK, H., HYUN, H.H. (2006) Optimization of culture conditions and medium composition for the production of micrococcin GO5 by Micrococcus sp. GO5. Journal of Biotechnology, 121(1), 54-61. http://dx.doi.org/10.1016/j.jbiotec.2005.06.022

KLEIN, G., PACK, A., BONAPARTE, C. AND REUTER, G. 1998. Taxonomy and physiology of probiotic lactic acid bacteria. International Journal of Food Microbiology, 41(2), 103-125. http://dx.doi.org/10.1016/S0168-1605(98)00049X

LEROY, F., DE VUYST, L. 1999. Temperature and $\mathrm{pH}$ conditions that prevail during the fermentation of sausages are optimal for the production of the antilisterial bacteriocin sakacin K. Applied and Environmental Microbiology, 65(3), 974-981

LIMA, J.R., RIBON, A.O., RUSSELL, J.B., MANTOVANI, H.C. 2009. Bovicin HC5 inhibits wasteful amino acid degradation by mixed ruminal bacteria in vitro. FEMS Microbiology Letters, 292(1), 78-84. http://dx.doi.org/10.1111/j.15746968.2008.01474.x

MANTOVANI, H.C., RUSSELL, J.B. 2003a. Inhibition of Listeria monocytogenes by bovicin HC5, a bacteriocin produced by Streptococcus bovis HC5. International Journal of Food Microbiology, 89(1), 77-83 http://dx.doi.org/10.1128/AAC.00109-08
MANTOVANI, H.C., RUSSELL, J.B. 2003b. Factors affecting the antibacterial activity of the ruminal bacterium, Streptococcus bovis HC5. Current Microbiology, 46(1), 18-23. http://dx.doi.org/10.1007/s00284-002-3786-0

MANTOVANI, H.C., HU, H., WOROBO, R.W., RUSSELL, J.B. 2002. Bovicin HC5, a bacteriocin from Streptococcus bovis HC5. Microbiology, 148, $3347-$ 3352

MANTOVANI, H.C., KAM, D.K., HA, J.K., RUSSELL, J.B. 2001. The antibacterial activity and sensitivity of Streptococcus bovis strains isolated from the rumen of cattle. FEMS Microbiology and Ecology, 37(3), 223-229. http://dx.doi.org/10.1111/j.1574-6941.2001.tb00869.x

MATARAGAS, M., METAXOPOULOS, J.,GALIOTOU, M., DROSINOS, E.H 2003. Influence of $\mathrm{pH}$ and temperature on growth and bacteriocin production by Leuconostoc mesenteroides L124 and Lactobacillus curvatus L442. Meat Science, 64(3), 265-271.

METSOVITI, M., PARAMITHIOTIS, S., DROSINOS, E.H., SKANDAMIS, P.N., GALIOTOU-PANAYOTOU, M., PAPANIKOLAOU, S. 2011.Biotechnological valorization of lowcost sugar-based media for bacteriocin production by Leuconostoc mesenteroides E131. New Biotechnology, 28(6), 600609. http://dx.doi.org/10.1016/j.nbt.2011.03.004

NEYSENS, P., DE VUYST, L. 2005. Carbon dioxide stimulates the production of amylovorin L by Lactobacillus amylovorus DCE 471, while enhanced aeration causes biphasic kinetics of growth and bacteriocin production. International Journal of Food Microbiology, 102(2), 191-202. http://dx.doi.org/10.1016/j.ijfoodmicro.2005.04.004

NIGUTOVA, K., MOROVSKY, M., PRISTAS, P., TEATHER, R.M., HOLO, H., JAVORSKY, P. 2007. Production of enterolysin A by rumen Enterococcu faecalis strain and occurrence of enlA homologues among ruminal Gram-positive cocci. Journal of Applied Microbiology, 102(2), 563-569. http://dx.doi.org/10.1111/j.1365-2672.2006.03068.x

PAIVA, A. D., BREUKINK, E., MANTOVANI, H. C. 2011. Role of Lipid II and Membrane Thickness in the Mechanism of Action of the Lantibiotic Bovicin HC5. Antimicrobial Agents and Chemotherapy, 55(11), 5284 5293. http://dx.doi.org/10.1128/AAC.00638-11

PIPER, C., COTTER, P.D., ROSS, R.P., HILL, C. 2009. Discovery of medically significant lantibiotics. Current Drug Discovery Technologies, 6(1), 1-18. http://dx.doi.org/10.2174/157016309787581075

REA, M.C., CLAYTON, E., O'CONNOR, P.M., SHANAHAN, F., KIELY, B. ROSS, R.P., HILL C. 2007.Antimicrobial activity of lacticin 3147 against clinical Clostridium difficile strains. Journal Medical Microbiology, 56, 940 946. http://dx.doi.org/10.1099/imm.0.47085-0

RUSSELL, J.B., MANTOVANI, H.C. 2002. The bacteriocins of ruminal bacteria and their potential as an alternative to antibiotics.Journal of Molecular Microbiology and Biotechnology, 4(4), 347-355

STATISTICAL ANALYSIS SYSTEMS. User`s guide: Stat.Version 9. Cary: SAS Institute, 2004

TODOROV, S.D., DICKS, L.M.T. 2006. Effect of medium components on bacteriocin production by Lactobacillus plantarum strains ST23LD and ST341LD, isolated from spoiled olive brine. Microbiological Research, 161(2), 102-108. http://dx.doi.org/10.1016/j.micres.2005.06.006

VAN DEN BERGHE, E., DE WINTER, T., DE VUYST, L. 2006. Enterocin A production by Enterococcus faecium FAIR-E 406 is characterized by a temperature- and $\mathrm{pH}$-dependent switch-off mechanism when growth is limited due to nutrient depletion. International Journal of Food Microbiology, 107(2), 159 -170. http://dx.doi.org/10.1016/j.ijfoodmicro.2005.08.027

WOLIN, M.J., MANNING, G.B., NELSIN, W.O. 1959. Ammonia salts as a sole source of nitrogen for the growth of Streptococcus bovis. Journal of Biotechnology, 13(1), 269-272.

YAMAZAKI, K., MURAKAMI, M., KAWAI, Y., INOUE, N., MATSUDA, T. 2000. Use of nisin for inhibition of Alicyclobacillus acidoterrestris in acidic $\begin{array}{llll}\text { drinks. Food } & \text { Microbiology, 315-320 }\end{array}$ http://dx.doi.org/10.1006/fmic.1999.0309 